\title{
Crónica
}

\section{Aborto terapéutico: Comisión de Salud del Senado aprobó idea de legislar}

\author{
http://www.colegiomedico.cl/Default.aspx?tabid $=760 \&$ selectmoduleid $=2494 \&$ Article \\ $\mathrm{ID}=852$
}

Con los votos a favor de los senadores Fulvio Rossi, Mariano Ruiz-Esquide y Guido Girardi, y en contra de los senadores Francisco Chahuán y Gonzalo Uriarte, la Comisión de Salud del Senado aprobó la idea de legislar sobre tres mociones que buscan regular el aborto terapéutico o por razones médicas. Se trata de una moción del senador Fulvio Rossi y la ex senadora Evelyn Matthei que despenaliza la interrupción del embarazo por razones médicas cuando hay riesgo vital de la madre o inviabilidad del feto; otra del senador Guido Girardi y el ex senador Carlos Ominami que además de esas dos causales agrega los casos de violación; y una tercera del senador Camilo Escalona que señala que se podrá interrumpir el embarazo, sólo con fines terapéuticos, mediante intervención médica, cuando esta sea documentada por dos médicos cirujanos.

Al término de la sesión, el presidente de la Comisión de Salud, Fulvio Rossi, manifestó que "acá tenemos un proyecto de ley que se hace cargo y le da respuesta al drama y al sufrimiento de muchas mujeres chilenas. Estamos hablando de cerca de 2 mil embarazos en donde hay inviabilidad fetal. ¿Tiene el Estado el derecho de imponerle a una mujer continuar con el embarazo a pesar de saber que es inviable?". Puntualizó que con la aprobación de la idea de legislar "e indistintamente en cada uno de estos proyectos se van a presentar indicaciones. Lo importante es que a partir de hoy se abre un debate nacional".

Una opinión similar manifestó el presidente del Senado y autor de una de las iniciativas, Guido Girardi, quien señaló que "me parece muy importante que la sociedad chilena, pueda discutir un instrumento que existió en Chile desde el año 1933 como el aborto terapéutico. Es legislar a favor de situaciones donde está en riesgo la vida de la mujer o hay situaciones de fetos inviables. Además creemos que es muy importante que cuando hay una violación en una niña adolescente que sea obligada a tener un hijo es una doble condena y luego una tercera condena si es sancionada por interrumpir ese embarazo".

A su turno, el senador Ruiz-Esquide dijo que "se trata de que deben hablarse las cosas y discutirse. Por eso voté a favor de la idea de legislar, porque creo que es necesario que el Senado lo debata, pero con mucha franqueza dije que los proyectos eran malos. Con todo el respeto que le tengo a mis colegas son proyectos innecesarios, malos porque la mitad de las cosas que allí se señalan están en el "ars medica" donde todos sabemos por las comisiones de bioética qué podemos hacer y qué debe hacerse".

Por su parte, el senador Chahuán explicó su voto en contra de las iniciativas argumentando que "nosotros consideramos que la legislación chilena, los pactos internacionales ratificados por Chile propenden a la defensa de la vida desde el momento mismo de la concepción. Vamos a generar las condiciones para que en la Sala del Senado sea rechazado, porque es un mal proyecto y vulnera un principio esencial del derecho a la vida... este es un proyecto innecesario que abre la válvula al aborto en Chile".

En la misma línea, el senador Uriarte señaló que se han realizado al menos cinco sesiones con especialistas para ver este tema. "Nosotros hemos participado de la discusión atentamente, hemos recibido a diversos especialistas y nos hemos formado convicción. Hay razones genéticas, biológicas, constitucionales, penales y sobre todo desde el punto de vista de la administración de justicia, para concluir que este es un mal proyecto, no se justifica, es innecesario y lo único que hace es retroceder en lo que todos queremos que es defender el derecho a la vida". 